ISSN 0853-8697

\title{
SOLAR HEATING OF AIR BY USIN G A FLAT PLATE COLLECTOR IN COMBINATION WITH HEAT EXCHANGING PIPES
}

\author{
H aidar M ahdi H ussain \\ International Program, Faculty of Industrial Technology, Islamic U niversity of Indonesia \\ Jl. Kaliurang K m. 14 Y ogyakarta 55501 \\ Phone. (0274) 895287, Facs. (0274) 895007 ext. 148
}

\begin{abstract}
ABSTRAK
Penelitian ini tentang pemanfaatan tenaga surya untuk pemanas udara lewat penggunaan sebuah kolektor energi surya berbentuk pelat datar (Type T-39) yang dikombinasikan dengan pipa-pipa saluran pertukaran panas pada sebuah ruang pertukaran panas. Hal ini bertujuan untuk memperoleh hubungan antara efisiensi kol ektor $(\eta)$ sebagai fungsi temperatur air rata-rata $\left(\mathrm{T}_{\text {avg }}\right)$ dan kecepatan al iran air $(\mathrm{V})$.

Kolektor energi surya ini dirancang menjadi sebuah tipe kolektor yang tidak dapat digerakkan namun dapat berfungsi dengan baik sebagai pemanas air. Proses pemanasan alat ini menggunakan dua media yaitu pemanas udara dan air. Alat ini bekerja lewat variasi kecepatan air yang mengalir di dalam kolektor dan dengan memperhitungkan kecepatan udara yang melalui pipa-pipa saluran pertukaran panas yang berhubungan dengan kolektor tersebut, maka kondisi optimum proses pemanasan udara dapat diindikasi pada jarak-jarak tertentu antara tabung-tabung bilik pertukaran panas.

$\mathrm{H}$ asil penelitian ini menunjukkan bahwa waktu efektif pemanasan berlangsung mulai dua jam sebel um tengah hari hingga dua jam sesudahnya. U ntuk pemanasan udara, sebuah persamaan umum efisiensi kolektor diperoleh melalui hubungan antara temperatur air rata-rata yang mengalir di dalam kolektor $\left(\mathrm{T}_{\text {avg }}\right)$ dan kecepatan air $(\mathrm{V})$, yaitu $\eta=$ 115,3336403 (Tavg)-0,097124 (V)-0,102206

Persamaan diatas mempunyai kesalahan standar sebesar 0,2375\%, dan berlaku pada kisaran temperatur $\left(T_{\text {avg }}\right.$ ) sebesar $15,86{ }^{\circ} \mathrm{C}$ hingga $31,48{ }^{\circ} \mathrm{C}$, dan pada kecepatan aliran sebesar 0,47 liter per 60 detik hingga 0,600 liter per 60 detik. Berdasarkan kondisikondisi operasi terapan tersebut, jumlah total transfer panas bertambah sejalan dengan berkurangnya kecepatan air di dalam kolektor yang dihubungkan dengan pipa-pipa saluran pertukaran panas.
\end{abstract}

Kata kunci: tenaga surya, kolektor, pelat datar, udara, saluran pertukaran panas

\section{BACKGROUND}

The search for alternative sources of energy will be a major preoccupation of the next generation of engineers and scientists. Solar energy can be expected to make a modest contribution, perhaps $3 \%$ of the energy needs of the United Kingdom by the year 2000, according to one prediction. While it is clear that, if this prediction is correct, the subject is not of overriding importance, it is nevertheless desirable that all professional engineers should have a sound general knowledge of the application of solar energy, and in particular should aware both of its potential and of its limitations. 
The subject falls naturally into two parts: the study of solar radiation itself, including the complex variations in intensity and quantity in different parts of the earth's surface, and the study of the various means of harnessing this energy for different purposes. The flat plate solar collector is a thermal solar energy collector and it is the basic device used in solar space and domestic water heating system. The operation of a flat plate solar collector is, in concept, simple. M ost of the solar energy incident on the collector is absorbed by a surface which is "black" to solar radiation. Part of the absorbed energy is transferred to a circulating fluid, while the rest is lost by heat transfer to the surroundings. The heat carried away by the fluid, the useful energy gain of the collector, is then either stored or used to supply the heating load. The essential parts of the collector are: the absorber plate, generally made of metal with a nonreflective black finish to maximize the absorption of solar radiation; pipes or ducts to circulate either liquid or air in thermal contact with the absorber plate; thermal insulation for the back side and edges of the plate; one or more air spaces separated by transparent covers to provide insulation for the top of the plate; and a housing to assure a durable and weatherable device.

The transparent covers are usually made of glass. Glass has excellent weatherability and good mechanical properties; it can be very transparent if it has a low iron oxide content, and it is relatively inexpensive. The disadvantages of glass as a cover material are that it is breakable and heavy. Plastics can also be used. They are generally less subject to breakage, light, and inexpensive in thin sheets. H owever, plastics generally do not have as high a resistance to weathering as glass; the surface can be scratched and many plastics degrade and yellow with age which reduces its transmittance to solar radiation and leads to loss in mechanical strength. One additional advantage of glass over plastics is that glass absorbs or reflects all of the long-wave radiation (heat) incident on it from the solar heated absorber plate, thus reducing radiation losses from the plate more effectively than plastics which transmit part of the long-wave radiation. The benefit of this research is to harness the solar energy for heating the air which would be used later for other purposes in industry, where the heated outside air is used in many industrial applications where recirculation of air is not practical because of contaminates, examples are drying, supplying fresh air to hospitals, and paint spraying operations, also in order to minimize the cost of operation in case using a conventional fuels for air heating in general. The objective of the research is studying and designing an application for the solar energy by using the present apparatus, the result of this research can indicate the effective conditions of operation and also obtaining values for the relation used in the calculation of the heat exchanging pipes equations.

The main goal of this research is to obtain:

1. Collector efficiency correlation as a function of temperature and water flow rate.

2. Comparing the values of $(C, n)$ which were obtained from this research, with the their values taken from the references. 


\section{THEORETICAL BASIS}

\subsection{Theory of Flat Plate Collector}

A solar collector is a special kind of heat exchanger that transforms solar radiant energy into heat. A solar collector differs in several respects from more conventional heat exchangers, the latter usually accomplish a fluid-to-fluid exchange with high heat transfer rates and with radiation as an unimportant factor. In the solar collector, energy transfer is from a distance source of radiant energy to fluid. The important parts of a typical liquid heating flat plate solar collector, are the "black" solar energy absorbing surface, with means for transferring the absorbed energy to a fluid; envelopes transparent to solar radiation over the solar absorber surface that reduce convection and radiation losses to the atmosphere; and back insulation to reduce conduction losses as the geometry of the system permits.

\subsection{Flat Plate Solar Energy Collector T-39}

The apparatus resembles the flat plate solar energy collectors that are al ready widely used for supplying hot water for domestic use and for the heating of swimming pools in many parts of the world, but it is fully instrumented to permit an assessment of its performance and an evaluation of the factors limiting the applicability of this method of absorbing solar energy in any particular location. The heater proper comprises a collecting plate which is constructed from two sheets of preformed stainless steel welded together to form integral parallel water channels. The surface of the plate is enclosed in an airtight box having a clear acrylic cover. Heat loss from the rear surface of the plate is minimized by the use of a thick layer of insulation material.

Calculations for Flat Plate Solar Energy Collector

Under conditions of steady radiation, the Steady Flow Energy Equation for the apparatus may be written:

$$
\mathrm{E} 1+\mathrm{Ep}=\mathrm{H}+\mathrm{L}
$$

Since the effective area of the collector is $1.5 \mathrm{~m}^{2}$, E1, the incident energy, is equal to the radiation intensity I and

$$
\mathrm{H}=(\mathrm{V} / \mathrm{t})(\mathrm{T} 3-\mathrm{T} 1) * 4186.8
$$

The losses from the collector are due mainly to the process of natural convection in the surrounding air and are given approximately by an equation in the form:

$$
\mathrm{L}=\text { constant } *[(\mathrm{~T} 1+\mathrm{T} 3) / 2-\mathrm{T} 4]^{1.3}
$$

The incident radiation is given by:

$$
\begin{aligned}
& \eta=\frac{\mathrm{H}-\mathrm{Ep}}{\mathrm{E} 1} \\
& \frac{\mathrm{E} 1}{1.5 \mathrm{~m}^{2}}=\mathrm{I}=\frac{\mathrm{v}}{\mathrm{KS}}
\end{aligned}
$$




\subsection{The H eat Exchanging Tubes and Chamber}

The solar heat will be transferred by using water as a media for the heat to be transferred from the flat plate solar collector to the air chamber in which the air will flows across tube banks which will be arranged in a staggered tube rows arrangement. A staggered tube row arrangement was chosen in order to increase the heat transfer area (tube's surface area) and in order to avoid using fins in case, the in-line tube rows arrangement were applied, because in the case of applying an in-line tube rows arrangement, the surface area of the heat transfer process should be increased. Without using fins, the heat transfer process will be absolutely useless, so by using staggered tube rows arrangement, the total manufacturing cost of this apparatus model or any other prototype can be minimized.

\subsection{Total H eat Transfer Calculation for the Tube Banks}

The total heat transfer per unit length for tube bank exit temperature can be calculated as follows:

$$
\begin{aligned}
& q=\text { h. A. }\left\{T_{w}-\left(T_{\infty, 1}+T_{\infty, 2}\right) / 2\right\} \\
& q=m . C p .\left\{T_{\infty, 1}+T_{\infty, 2}\right\}
\end{aligned}
$$

where:

$$
\begin{aligned}
& \mathrm{q}=\text { is the heat transfer rate }(\mathrm{W} / \mathrm{m}) \\
& \mathrm{m}=\text { is the mass flow rate }(\mathrm{Kg} / \mathrm{seC}) \\
& \mathrm{h}=\text { is the heat transfer coefficient }\left(\mathrm{W} / \mathrm{m}^{2} \cdot{ }^{\circ} \mathrm{C}\right) \\
& \mathrm{Cp}=\text { is the heat capacity of air }\left(\mathrm{J} / \mathrm{Kg} .{ }^{\circ} \mathrm{C}\right) \\
& \mathrm{T}_{\mathrm{W}}=\text { is the wall temperature of the tubes }\left({ }^{\circ} \mathrm{C}\right) \\
& \mathrm{T}_{\infty, 1}=\text { is the air inlet temperature }\left({ }^{\circ} \mathrm{C}\right) \\
& \mathrm{T}_{\infty, 2}=\text { is the air outlet temperature }\left({ }^{\circ} \mathrm{C}\right)
\end{aligned}
$$
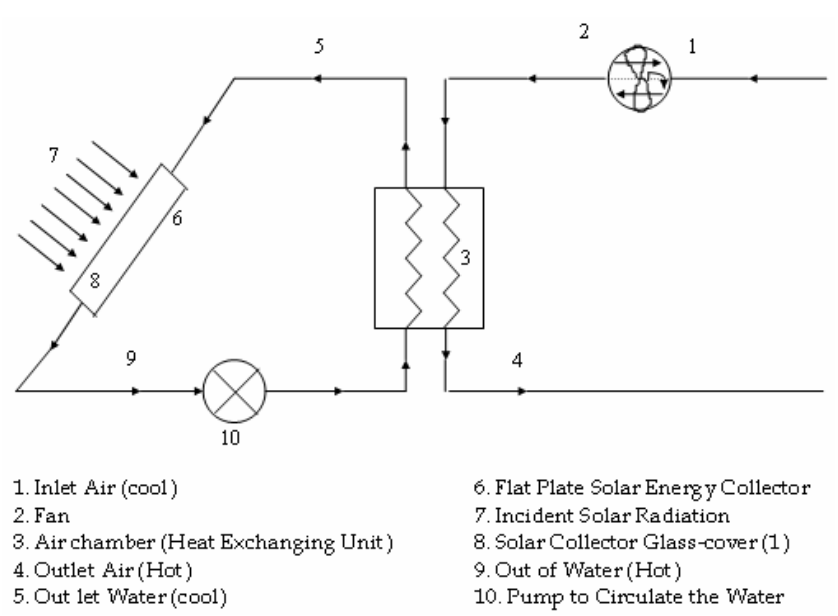

6. Flat Plate Solar Energy Collector

7. Incident Solar Radiation

8. Solar Collector Glass-cover (1)

9. Out of Water (Hot)

10. Pump to Circulate the Water

Figure 1. Schematic diagram of solar heating of air 
The heat transfer coefficient is then calculated with the following equation:

$$
(\text { h.d } / \mathrm{kf})=\mathrm{C} .\left(\mathrm{U}_{\infty} . \mathrm{d} / \text { of }\right)^{\mathrm{n}} . \mathrm{Pr}
$$

where:

$$
\begin{aligned}
& \mathrm{h}=\text { is the heat transfer coefficient }(\mathrm{W} / \mathrm{m} 2 . \mathrm{oC}) \\
& \mathrm{d}=\text { is the tube inside diameter }(\mathrm{m}) \\
& \mathrm{kf}=\text { is the thermal conductivity of air }(\mathrm{W} / \mathrm{m} 2 . \mathrm{oC}) \\
& \mathrm{U}_{\infty}=\text { is the air inlet velocity }(\mathrm{m} / \mathrm{sec}) \\
& \mathrm{Pr}=\text { is Prandtle number } \\
& \text { of }=\text { is air kinematics viscosity }
\end{aligned}
$$

\section{EXPERIMENTAL PROCEDURE}

After installing the solar collector, by making use of rubber hose, the collector will be connected to the heat exchanging pipes, then turning on the water supply and opening the air vent at the top of the collector panel, leaving it open until all the air in the system "including the heat exchanging pipes" has been expelled and the water is emitted. Starting the circulating pump, shutting the vent valve and then reducing the water supply to a trickle.

The above procedure should be repeated for different water flow rates through the collector, changing the flow rate of the water in each time by reducing the water supply to a trickle, then results can be obtained for different flow rates. Water flow rate through the collector can be measured by using a glass measuring vessel and a stopwatch for the water discharge from a branch pipe located between the heater outlet stream and the pump. The thermocouple wires should be set in the inlet point to the collector (T1) and the mixed water stream (T2) and the outlet hot water from the collector (T3).

The data that should be recorded from the flat plate collector are: T1, T2, T3, T4 and the solarimeter output, giving enough time after starting the instruments, the data is recorded around two hours before midday to two hours after midday which is the effective period of day in which solar energy can be collected. By starting recording data two hours before midday from the flat plate collector in the same time recording data from the heat exchanging pipes which are the tube wall average temperature (TW), the inlet air temperature $\left(T_{\infty, 1}\right)$ and the outlet air temperature $\left(T_{\infty, 2}\right)$ from the air chamber.

For the flat plate collector, data should be recorded every 15 minutes in order to obtain different data that allow an analysis on them, where the change in the water temperature can be measured and for the heat exchanging pipes data should be recorded every half an hour, where this period is necessary for the temperature of the tube wall or the air that passes through the tube bank to be recorded. The above procedure should be repeated for several water flow rates.

\section{RESULTS AND DISCUSSION}

\subsection{Flat Plate Collector}

After collecting data from flat plate collector, and after following the procedures of calculation described in the thesis of this publication copy (see Tabel 1) can be calculated. This table represents an example of the results obtained 
from the calculation and data observation. A basic conclusion that can be drawn from the Figure 2 is the solar collector efficiency drastically decreases with temperature increasing of the water that flows through the collector, or it can be said that with the mean water temperature $[(\mathrm{T} 2+\mathrm{T} 3) / 2$ - T4] flowing through the collector.

Table 1. Flat plate solar energy collector

\begin{tabular}{|c|c|c|c|c|c|c|c|c|c|c|c|}
\hline TIME & $\begin{array}{c}\mathrm{Vs} \\
(\mathrm{m} / \mathrm{s})\end{array}$ & $\begin{array}{c}\mathrm{E} 1 \\
(\mathrm{~W} / \mathrm{m} 2)\end{array}$ & $\mathrm{H}$ (Watt) & $\eta$ \% & TIME & $\mathrm{T}_{3} /{ }^{\circ} \mathrm{C}$ & $\mathrm{TIME}$ & $\mathrm{T}_{2} /{ }^{\circ} \mathrm{C}$ & $\begin{array}{c}(\mathrm{T} 2+\mathrm{T} 3)^{1 / 2} \\
\mathrm{~T}_{4}\end{array}$ & $\mathrm{~L}$ & $\begin{array}{c}\text { L's } \\
\text { constant }\end{array}$ \\
\hline $10: 00$ & 72.0 & 1008.0 & 992.44 & 93.0 & $10: 00$ & 57.96 & $10: 00$ & 49.30 & 20.75 & 70.56 & 1.3691 \\
\hline $10: 15$ & 75.3 & 1054.2 & 1034.35 & 92.9 & $10: 15$ & 59.23 & $10: 15$ & 49.95 & 21.73 & 74.83 & 1.3687 \\
\hline $10: 30$ & 77.2 & 1080.8 & 1055.82 & 92.6 & $10: 30$ & 59.90 & $10: 30$ & 50.30 & 22.25 & 79.98 & 1.4173 \\
\hline $10: 45$ & 80.8 & 1131.2 & 1095.74 & 92.0 & $10: 45$ & 61.10 & $10: 45$ & 50.90 & 23.75 & 96.50 & 1.5230 \\
\hline $11: 00$ & 87.1 & 1219.4 & 1179.53 & 91.4 & $11: 00$ & 63.36 & $11: 00$ & 52.00 & 24.80 & 104.87 & 1.6138 \\
\hline $11: 15$ & 89.8 & 1257.2 & 1200.31 & 91.1 & $11: 15$ & 64.30 & $11: 15$ & 52.50 & 25.55 & 111.89 & 1.6564 \\
\hline $11: 30$ & 95.3 & 1334.2 & 1263.78 & 90.6 & $11: 30$ & 66.23 & $11: 30$ & 53.45 & 26.98 & 125.42 & 1.7303 \\
\hline $11: 45$ & 100.1 & 1401.4 & 1320.46 & 90.3 & $11: 45$ & 67.96 & $11: 45$ & 54.30 & 28.25 & 135.94 & 1.7661 \\
\hline $12: 00$ & 105.3 & 1474.2 & 1381.78 & 90.0 & $12: 00$ & 69.80 & $12: 00$ & 55.25 & 29.68 & 147.42 & 1.7965 \\
\hline $12: 15$ & 108.2 & 1514.8 & 1412.26 & 89.6 & $12: 15$ & 70.76 & $12: 15$ & 55.70 & 30.35 & 157.54 & 1.8646 \\
\hline $12: 30$ & 110.1 & 1541.8 & 1031.06 & 89.3 & $12: 30$ & 71.33 & $12: 30$ & 56.00 & 30.80 & 165.74 & 1.9244 \\
\hline $12: 45$ & 110.8 & 1551.2 & 1038.67 & 89.2 & $12: 45$ & 71.56 & $12: 45$ & 56.10 & 30.95 & 167.53 & 1.9330 \\
\hline $13: 00$ & 112.5 & 1575.0 & 1458.33 & 89.1 & $13: 00$ & 72.20 & $13: 00$ & 56.45 & 31.48 & 171.68 & 1.9379 \\
\hline $13: 15$ & 103.5 & 1449.0 & 1356.20 & 89.8 & $13: 15$ & 69.05 & $13: 15$ & 54.85 & 29.68 & 147.20 & 1.8496 \\
\hline $13: 30$ & 95.0 & 1330.0 & 1250.80 & 89.9 & $13: 30$ & 65.83 & $13: 30$ & 53.25 & 26.68 & 134.20 & 1.8784 \\
\hline $13: 45$ & 89.4 & 1251.6 & 1180.94 & 90.0 & $13: 45$ & 63.70 & $13: 45$ & 52.20 & 25.10 & 125.66 & 1.9038 \\
\hline $14: 00$ & 84.9 & 1188.6 & 1127.12 & 90.2 & $14: 00$ & 62.60 & $14: 00$ & 51.40 & 23.83 & 116.48 & 1.8884 \\
\hline
\end{tabular}

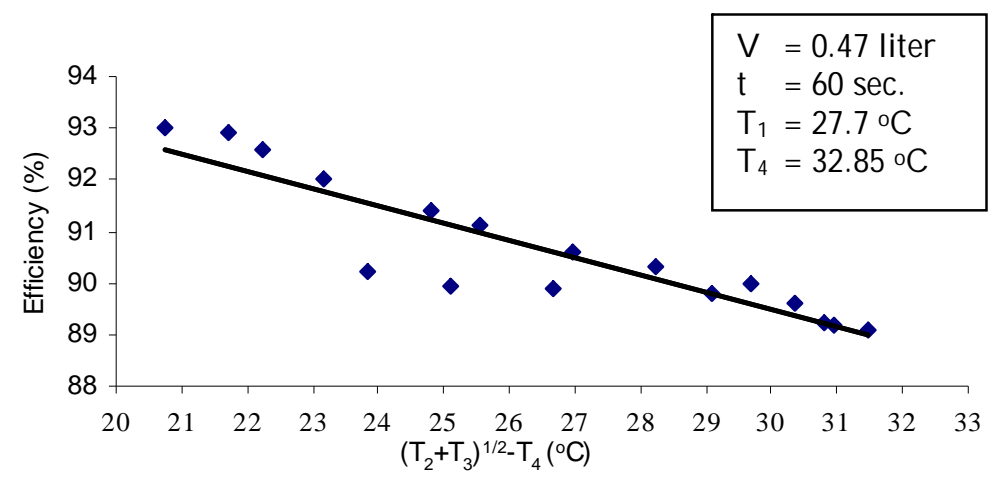

Figure 2. Collector efficiency relation with mean water temperature

Table 4 shows that the effective period of solar collection is around two hours before to two hours after midday, it is also obvious that the intensity of the

Hussain - Solar H eating of Air by U sing a Flat Plate Collector in Combination with ... 
sunlight falls rapidly after the midday, this surely depends on several factors like the location of the collector on earth's surface, the time of the day and the time of the year. Also the heat losses from the collector increase with increasing the water mean temperature. In another word the collector efficiency decreases with increasing heat loss from the collector and this can be explained as follows: the higher the water mean temperature, the higher the heat lost from the collector. The heat loss is in two forms, convection and conduction through the collector top, edges, and back insulation's, also the heat lost due to natural convection from the collector plate surface to collector cover and then to the surrounding. The other form of loss could be the loss of heat (absorbed from the sun light) due to the reflection of radiation from the collector surface, so this kind of loss depends on the emittance of the collector surface plate and the reflection and absorption of radiation through and within collector cover. Although the previous heat loss was minimized by using an acrylic cover, nevertheless this kind of heat loss can never be avoided because it always relates to some natural phenomena that could be minimized but never be avoided or eliminated. The collector efficiency can be considered increasing with increasing the flow rate of water flowing through it, nevertheless, in experiments this efficiency does not greatly differ because the difference between the applied flow rates can be considered small. The explanation for the collector efficiency and its relation with the water flow rate flowing through it is: higher the flow rate of water through the collector, less heat lost from the collector because, the heat absorbed by the collector plate from the sunlight is directly transferred to the flowing fluid, so the residence time of this fluid is less in the collector and that gives shorter time for the heat to be lost through the collector insulation and cover.

\subsection{Heat Exchanging Pipes}

In Table 2, the experimental values of heat transfer coefficient (h) depend on $\quad(\mathrm{Q}=\mathrm{m} . \mathrm{Cp} . \Delta \mathrm{T})$ which itself depends on the assumption that there is no heat lost to the surround through the walls of the heat exchanging pipes, in another word the heat transfer was only in the flow direction while in the theoretical case of obtaining the value of the heat transfer coefficient $(\mathrm{h})$ was based on the value of Reynolds number $(\mathrm{Re})$ in the following equation:

$$
\begin{aligned}
& \mathrm{Nu}=\mathrm{C} \cdot(\operatorname{Re})^{\mathrm{n}} \cdot(\operatorname{Pr})^{1 / 3} \\
& (\mathrm{~h} \cdot \mathrm{d} / \mathrm{Kf})=\mathrm{C} \cdot(\rho \cdot \mathrm{u} \cdot \mathrm{d} / \mu)(\mu \cdot \mathrm{Cp} / \mathrm{K})
\end{aligned}
$$

The lack of high accuracy of measuring of the tube wall temperature (Tw) effected on the physical properties of the air flowing through the tube banks, and that due to the assumption of constant tube wall temperature or by considering their average temperatures. This assumption can not be satisfied for this apparatus because the temperature distribution on the tube will be in two directions, the first one is parallel to the flow direction of water inside the tubes, and the second one is normal to the flow direction of the water inside the tubes (the air flow direction).

Table 2. Experimental and theoretical values of heat transfer coefficient (h) 


\begin{tabular}{|c|c|c|}
\hline \multicolumn{3}{|c|}{$\begin{array}{l}\text { Air inlet temperature }\left(\mathrm{T}_{\infty, 1}\right)=32.8^{\circ} \mathrm{C} \\
\text { Air inlet velocity }\left(\mathrm{U}_{\infty_{1}, 1}\right)=1 \mathrm{~m} / \mathrm{sec} \\
\text { Air outlet velocity }\left(\mathrm{U}_{\infty, 2}\right)=5 \mathrm{~m} / \mathrm{sec} \\
\text { Flow rate in the collector measuremer }\end{array}$} \\
\hline Time (hr) & $\underline{\mathrm{h}\left(\mathrm{W} / \mathrm{m}^{2} \cdot{ }^{\circ} \mathrm{C}\right)_{\text {theoretical }}}$ & $\underline{\mathrm{h}\left(\mathrm{W} / \mathrm{m}^{2} \cdot{ }^{\circ} \mathrm{C}\right) \text { experimertal }}$ \\
\hline $10: 00-11: 00$ & 53.328837 & 43.0419 \\
\hline $11: 00-11: 30$ & 53.31822 & 43.84961 \\
\hline $11: 30-12: 00$ & 53.31076 & 47.90423 \\
\hline $12: 00-13: 00$ & 53.30112 & 49.58950 \\
\hline $13: 00-13: 30$ & 53.30820 & 46.92976 \\
\hline $13: 30-14: 00$ & 53.32106 & 42.16297 \\
\hline
\end{tabular}

The values of the constant $(C, n)$ taken from the references are depending on the values of $(\mathrm{Re})$ and $(\mathrm{Pr})$ which themselves depend on the flow conditions (air velocity, tube's arrangement, the roughness of the external surface of the tubes) and on the properties of fluid which change with temperature and pressure. While the theoretical calculations for the values of $(\mathrm{C}, \mathrm{n})$, deals with equation $\mathrm{Nu}$ $=\mathrm{C} \cdot \operatorname{Re}^{n} \cdot \operatorname{Pr}^{1 / 3}$ ) as a pure mathematical equation, in another word, (C)is a mathematical parameter that does not depend on another parameter or variable, and $(n)$ is an exponent also does not depend on its variable (Re). The new values of $(C, n)$ were obtained by the method of linear regression with the aid of computer program.

Table 3. Experimental values of the constants $\mathrm{C}$ and $\mathrm{n}$

\begin{tabular}{ll}
$\mathrm{C}=0.478$ & Air inlet temperature $=32.8^{\circ} \mathrm{C}$ \\
$\mathrm{n}=0.620$ & Flow rate in collector measurement $=0.47$ Liter per $\mathrm{t}=60 \mathrm{seC}$ \\
$\mathrm{C}=0.475$ & Air inlet temperature $=32.7^{\circ} \mathrm{C}$ \\
$\mathrm{n}=0.632$ & Flow rate in collector measurement $=0.53$ Liter per $\mathrm{t}=60 \mathrm{seC}$ \\
& \\
$\mathrm{C}=0.477$ & Air inlet temperature $=33^{\circ} \mathrm{C}$ \\
$\mathrm{n}=0.616$ & Flow rate in collector measurement $=0.60$ Liter per $\mathrm{t}=60 \mathrm{seC}$ \\
\hline
\end{tabular}

General values of $(C, n)$ can be estimated by considering their average value, so the average values of $C \& n$ as follows:

$$
\mathrm{C} \approx 0.476 \quad \mathrm{n} \approx 0.632
$$

The conclusion that as greater the flow rate of water through the collector as less heat transferred to the air through the tube banks, can be drawn from observing the tables in thesis that deal with the tube wall temperature and the flow rate of water in the collector. The values of theoretical air outlet temperature are higher than those of experimental and this can be explained in the same way for the same reason of the difference between the experimental and the theoretical heat transfer coefficient (h) values (see Table (4)).

Table 4. Theoretical and experimental air temperature 


\begin{tabular}{|c|c|c|c|c|c|c|}
\hline \multirow{3}{*}{\multicolumn{4}{|c|}{\begin{tabular}{|c|} 
Air inlet Temperature $\left(T_{\infty}, 1\right)=32.7 \circ \mathrm{C}$ \\
Air inlet Velocity $\left(U_{\infty, 1}\right)=1 \mathrm{~m} / \mathrm{sec}$ \\
Air outlet Velocity $\left(U_{\infty, 2}\right)=5 \mathrm{~m} / \mathrm{sec}$ \\
Flow rate in the Collector M easuremen \\
$\begin{array}{c}\text { (Tube Wall A verage Temperature) } \\
\text { Pipes A verage Temperature }\end{array}$
\end{tabular}}} & \multicolumn{2}{|c|}{$\begin{array}{l}C=0.535 \\
n=0.556 \\
\text { sec. }\end{array}$} & \\
\hline & & & & \multirow{3}{*}{ Time (hr) } & \multicolumn{2}{|c|}{ Air Outlet Temperature } \\
\hline & & & & & $\mathrm{T}_{\propto, 2}\left({ }^{\circ} \mathrm{C}\right)$ & $\mathrm{T}_{\propto, 2}\left({ }^{\circ} \mathrm{C}\right)$ \\
\hline $\mathrm{T}_{1}(\mathrm{oC})$ & $\mathrm{T}_{2}(\mathrm{oC})$ & $\mathrm{T}_{3}(\mathrm{oC})$ & $\mathrm{T}_{\text {avg }}(\mathrm{oC})$ & & (Experimental & (Theoretical) \\
\hline 56.5 & 56.0 & 55.7 & 56.0 & $10: 00-11: 00$ & 36.570 & 36.54 \\
\hline 59.3 & 59.0 & 58.7 & 59.0 & $11: 00-11: 30$ & 36.50 & 37.00 \\
\hline 64.5 & 63.9 & 63.9 & 64.0 & $11: 30-12: 00$ & 37.10 & 37.85 \\
\hline 66.5 & 66.1 & 66.0 & 66.2 & 12:00-13:00 & 37.85 & 38.21 \\
\hline 65.0 & 64.5 & 64.0 & 64.5 & 13:00-13:00 & 37.50 & 37.93 \\
\hline 60.2 & 60.1 & 59.8 & 60.0 & 13:30-14:00 & 36.80 & 37.20 \\
\hline
\end{tabular}

The value of Prandtle number power (1/3) is basically based on the hydraulic equation (External Flow Equation).

A question remained to be answered, why fins were not used in our research, the answer for this question could be as follows: First because the air velocity used in the heat exchanging pipes were very low, second the temperature difference in the heat source (solar collector) was small difference, so there was not any need to increase the heat exchanging surface, al so the tubes arrangement and their applied distances make the fins retard the air flow and increase the drag force, also the formation of a boundary layer resulted from increasing the surface area, so with this low velocity the flow on this wide surface will be laminar which decreases the heat transfer coefficient (h), "as we already know that the value of $(\mathrm{h})$ decreases in the boundary layer with increasing the length in the external direction".

\section{CONCLUSIONS}

The conclusions that can be drawn from the results of this research are:

a. The efficiency of the flat plate solar energy collector falls with increasing the temperature of water passing through it.

b. The overall or total amount of heat loss increases with increasing temperature of the water passing through the collector.

c. Collector efficiency arises with increasing the flow rate of water passing through the collector.

d. The general relation (equation) of the collector efficiency with the mean water $\left(T_{\text {avg }}\right)$ and with the water flow rate $(\mathrm{V})$ is:

$$
\eta=115.3336403 .\left(T_{\text {avg }}\right)^{-0.097124} .(V)^{-0.102206}
$$

where the mean or the standard of this equation is equal to $(0.2375 \%)$, and the range of $\left(T_{\text {avg }}\right)$ is $\left(15.86^{\circ} \mathrm{C}\right)$ to $\left(31.48{ }^{\circ} \mathrm{C}\right)$, and for a flow rate is $(0.47$ liter per 60 $\mathrm{sec})$ to $(0.600$ liter per $60 \mathrm{sec})$.

e. The assumption of constant surface temperature of tube's wall in the heat exchanging pipes, can never be practically satisfied in any kind of external flow, since there are two kinds of flow; external and internal flow that effect 
on the temperature distribution in both direction, so that makes it even more difficult to obtain a constant surface temperature.

f. If the tube's dimensions (Sp,Sn) changed by making the normal distance (Sn) greater than the applied (Sn), so a higher value of (n) will be obtained, consequently a higher value of heat transfer coefficient (h) will be obtained.

g. The theoretical values of the heat transfer coefficient $(h)$ differ from the experimental values and differs from the those values calculated based on the new values of $(C, n)$.

h. The value of heat transfer coefficient varies with location in the heat exchanging pipes, depending on the flow conditions in every point and also on the temperature in each point, therefore we can notice that there is difference between $(\mathrm{h})$ values when using equation $(\mathrm{Q}=\mathrm{m} . \mathrm{Cp} . \Delta \mathrm{T})$ and those values of $(h)$ obtained from equation $\left(N u=C\right.$. Ren. $\left.\operatorname{Pr}^{1 / 3}\right)$ where the latter basically depends on the tube diameter and the physical properties of air in every point, so in order to obtain more accurate values of the heat transfer coefficient (h) "empirical values" we should know about the temperature distribution of the entire system, consequently evaluating the physical properties at temperature $\left[T f=\left(T_{\infty .1}+T_{\infty . x}\right)\right]$; where $(x)$ is the distance along the tube.

\section{REFEREN CES}

[1] Beckman, W.A., Klein, S.A., and Duffie, J.A. (1980) Solar Heating Design, Wiley-Interscience Publication, Madison, Wisconsin.

[2] Duffie, J.E., and Beckman, W.A. (1977) Solar Engineering of Thermal Processes, Wiley-Interscience Publication, Madison, Wisconsin.

[3] Hastwell, P.J. (1978) Handout: Energy \& Solar Energy, Applied Research of Australia pty Limited, 13 Durant Road, Croydon Park, South A ustralia 5008.

[4] Holman, J.P. (1983) H eat Transfer, M cGraw-Hill, Southern Methodist.

[5] Kreider, J.F. and Kreith, F. (1981) Solar Energy Handbook, McGraw-Hill, United States of A merica.

[6] Loehnke, R.I. (1990) A Passive, Vapor Compression Refrigeration for Solar Cooling, J. Solar En. Eng., Vol. 112, No. 3, 191-195.

[7] Patil, B.G. and Word, G.T. (1989) Simulation of Solar Air Drying of Rapeseed, Solar Energy, Vol. 43, No. 5, 305-320.

[8] Plint \& Partners Ltd. (1984) M anual, TE 39, Oaklands, Wokingham, Berkshire RG 11 2FD, England

[9] Refrigeration Science and Technology (1982) Solar Energy for Refrigeration and Air Conditioning, International Institute of Refrigeration, Paris, France.

[10] Wibulswas, P. (1984) Solar Distillation and Solar Refrigeration, Solar Thermal Processes in Thailand, 9-53. 